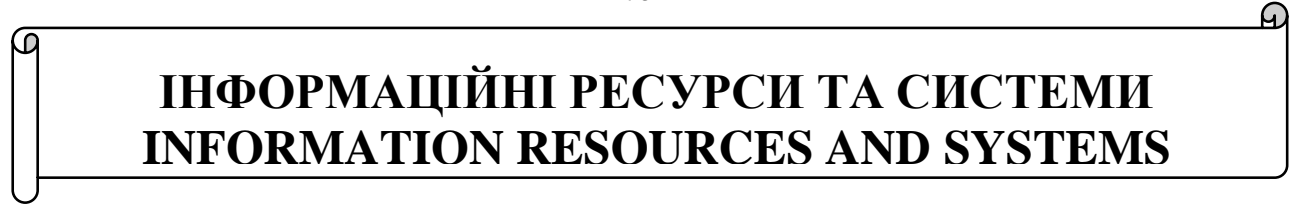

УДК 049.3:574.4:581.526

Sergii I. Azarov ${ }^{1}$, D. S. (Engineering), Senior research associate ORCID ID 0000-0002-9951-8867 e-mail: azarov@kinr.kiev.ua

Oleksii S. Zadunaj ${ }^{2}$, PhD, Head of the center

ORCID ID 0000-0001-8589-1604 e-mail: a.zadunaj@gmail.com

${ }^{1}$ Institute for Nuclear Research of NASU, Kyiv, Ukraine

${ }^{2}$ State Research Institute of Cybersecurity Technologies and Information Protection, Kyiv, Ukraine

\title{
ANALYSIS OF NATURAL DISASTERS AND THEIR IMPACT ON THE ENVIRONMENT
}

Summary. Millions of lives could be saved if states did more to prevent and reduce the risks of natural disasters. Protecting people from all sorts of disasters and accidents - one of the priorities in many countries. The disasters that have occurred show that natural disasters have no boundaries and do not choose the people. Especially in recent years, the challenge of natural disasters, accompanied by climate change, floods, mudslides, earthquakes, droughts and fires, is increasing. The quantity and total damage of the natural disasters has increased in recent years. Global changes in the environment and climate, increasing levels of seismic activity of the Earth's crust, increasing the size and power of technical systems used, progressive human intervention in nature increase the risks of large-scale natural, environmental and man-made disasters. The rate of growth of economic losses from catastrophes is reaching the indicators of economic development of most developed countries and poses a global threat to the population, nature and the world economy. The article performs analysis of the natural disasters occurred in the world and their impact on environment. Knowledge of the causes, dynamics and nature of natural disasters can reduce the threat to life and health of people, prevent or reduce material and economic losses in business, effectively carry out a complex of preventive, rescue and emergency work associated with natural disasters.

Analyzed the specific situation of occurrence of natural disasters. Particular attention is paid to assessing economic and social losses from natural disasters.

Keywords: natural disasters; consequences of natural disasters; loss; climate destabilization; gross national product

(C) S.I. Azarov, O.S. Zadunaj, 2019 


\section{С.I. Азаров ${ }^{1}$, О.С. Задунай ${ }^{2}$}

${ }^{1}$ Інститут ядерних досліджень НАН України, м. Київ, Україна

${ }^{2}$ Державний науково-дослідний інститут технологій кібербезпеки та захисту інформації, м. Київ, Україна

\section{АНАЛІЗ ПРИРОДНИХ КАТАСТРОФ ТА ЇХ ВПЛИВУ НА ДОВКІЛЛЯ}

Анотація. Мільйони життів можна було б врятувати, якби держави більше робили для попередження $i$ скорочення ризиків стихійних лих. Захист населення від всіляких лих $і$ катастроф - один з найбільш пріоритетних напрямків діяльності багатьох держав світу. Катастрофи, які сталися, показують, що стихійні лиха не мають кордонів $і$ не вибирають народ. Особливо в останні роки посилилися виклики природних катаклізмів, що супроводжуються кліматичними змінами, повенями, селевими потоками, землетрусами, засухами $i$ пожежами. Кількість природних катастроф зросла і до того ж вони стають все масштабніше за розмірами завданої шкоди. Глобальні зміни природного середовища і клімату, підвищення рівня сейсмічної активності земної кори, збільшення розмірів $і$ потужності використовуваних технічних систем, прогресуюче втручання людини 6 природу підсилюють ризики великомасштабних природних, екологічних $i$ техногенних катастроф. Темпи зростання економічних збитків від катастроф досягають показників економічного розвитку більшості розвинених краӥн і представляють глобальну загрозу для населення, природи $i$ світової економіки. В статті розглянуто задачу аналізу природних катастроф, які відбулися в світі, та їх вплив на навколишне середовище. Знання причин виникнення, динаміки розвитку та характеру вражаючих факторів природних катастроф дозволяе зменшити загрозу життю $i$ здоров'ю людей, запобігти або зменшити матеріальні та економічні збитки y підприємницькій діяльності, ефективно проводити комплекс попереджувальних, рятувальних та аварійних робіт, пов'язаних з природними катастрофами.

B роботі аналізуються конкретні ситуачії виникнення природних катастроф. Особливу увагу приділено оціниі економічних і соџіальних втрат від стихійних лих.

Ключові слова: природні катастрофи; наслідки стихійних лих; збиток; дестабілізаџія клімату; валовий наџіональний продукт

\section{Вступ}

Людство 3 найдавніших часів відчуває фатальний страх перед природною стихією. Здавалося б, з розвитком наукових знань про природні катастрофи $\mathrm{i}$ технологій захисту загроза людству в разі виникнення катастроф повинна зменшуватись. Однак статистика стверджує зворотне: число постраждалих від катастроф збільшується щорічно приблизно на 6\%. Це пояснюється швидким зростанням кількості населення і високою концентрацією людей в містах, деградацією навколишнього середовища, що сприяє інтенсифікації небезпечних природних процесів, комунікаційним i технологічним роз'єднанням багатьох країн світу. Природні катастрофи, в їх широкому спектрі прояву, практично у всіх сферах нашого життя в усі часи вселяли i вселяють людству містичний страх перед їх фатальною неминучістю i фатальною непередбачуваністю. Кількість природних катастроф останнім 
часом зросла і до того ж вони стають все масштабнішими за розмірами завданої шкоди. Глобальні зміни природного середовища і клімату, підвищення рівня сейсмічної активності земної кори, збільшення розмірів і потужності використовуваних технічних систем, прогресуюче втручання людини в природу підсилюють ризики великомасштабних природних, екологічних і техногенних катастроф. Темпи зростання економічних збитків від катастроф досягають показників економічного розвитку більшості розвинених країн і представляють глобальну загрозу для населення, природи і світової економіки.

Природна катастрофа - це різка швидкоплинна зміна стану навколишнього середовища 3 великою кількістю жертв і значним матеріальним збитком. Природна катастрофа - це надзвичайна ситуація (НС), що виникає в результаті стихійних лих, внаслідок чого створюється несприятлива обстановка на певній території, що може спричинити людські жертви, завдати шкоди здоров'ю людей i навколишньому середовищу, значних матеріальних втрат і призвести до порушення життєдіяльності населення. У багатьох країнах проводяться дослідження зі складання бази даних природних катастроф, вивчення їх поширення на різних територіях земної кулі. Знання динаміки кількості природних катастроф в світі дозволяє виробити політику щодо захисту населення і економіки від великих втрат і збитків при виникненні стихійних лих.

Однак в ході вивчення історії природних катастроф, що відбулися, і їх екологічних наслідків, розширення бази знань про них, на перший план виходить необхідність проведення подальших досліджень 3:

розвитку і вдосконалення стратегії взаємодії людини і природи для забезпечення сталого розвитку;

аналізу знань передісторії стихійних лих і пошуку шляхів використання цих знань для оцінок майбутніх тенденцій в подальшому розвитку цивілізації, що дозволяють виявляти граничні навантаження на природу;

усвідомлення ролі і місця існування людства в екологічно безпечному стані.

Особливо важливим завданням $є$ передбачення екологічних наслідків природних катастроф, які можуть проявлятися, поступово зростаючи, через десятиліття у вигляді зниження продуктивності екосистем, зміни структури водного балансу території та порушення життєво важливих параметрів навколишнього середовища. На жаль, комплексних методів аналізу природних катастроф, які відбулися в світі, та їх впливу на довкілля в повній мірі поки що немає. Тому наукові розробки в цьому напрямку є дуже актуальними.

\section{Класифікація природних катастроф}

Природна катастрофа являє собою стихійне лихо, що призводить до загибелі людей і значних економічних збитків. Такі наслідки часто спричиняють землетруси, зсуви, снігові лавини, обвали, сходи льодовиків, повені, виверження вулканів, лісові пожежі, грози, торнадо, шторми, спека, урагани та інше.

Поняття природної катастрофи у багатьох авторів [1] асоціюється 3 поняттям екологічної безпеки, яке з'явилось в зв'язку з необхідністю оцінки небезпеки для населення якоїсь території з точки зору отримання збитку для здоров'я, споруд або майна в результаті змін параметрів навколишнього середовища. Ці зміни можуть бути викликані як природними, так i 
антропогенними причинами. У першому випадку небезпека виникає за рахунок флуктуацій в природних процесах, пов'язаних зі зміною синоптичної обстановки, виникненням епідемії або за рахунок стихійного лиха. У другому випадку небезпека з'являється як реакція природи на дії людини. Природні катастрофи небезпечні своєю несподіваністю, за короткий проміжок часу вони спустошують територію, знищують житло, майно, комунікації. За однією катастрофою, немов лавина, ідуть інші: голод, інфекції, хвороби.

Усі природні катастрофи підпорядковуються деяким загальним закономірностям [2].

По-перше, для кожного виду природної катастрофи характерна певна просторова приуроченість. По-друге, чим більше інтенсивність (потужність) небезпечного природного явища, тим рідше воно трапляється. По-третє, кожному стихійному лиху природного характеру передують деякі специфічні ознаки (передвісники). По-четверте, при всій несподіванці тієї чи іншої природної катастрофи іiі прояв може бути передбачений. Нарешті, по-п'яте, у багатьох випадках можуть бути передбачені пасивні та активні захисні заходи від природних небезпек.

Як уже зазначалося, природні катастрофи призводять до загибелі людей та великих економічних збитків. Різноманіття причин, що призводять до виникнення цих стихійних природних явищ, створює певні труднощі в їх прогнозуванні, тим самим спроможність запобігання великим втратам поки залишається вельми низькою.

Природні катастрофи діляться на:

1. Геологічні: землетруси, виверження вулканів, зсуви, карст;

2. Метеорологічні: ураган, буря, смерч, шквал, злива, град, сильний снігопад, ожеледь, сильний мороз, сніжна лавина, сильна спека, посуха, пилова буря, природна пожежа;

3. Гідрологічні: повені, сель, ранній льодостав, ранній лісосплав;

4. Морські стихійні лиха: тропічний циклон (тайфун), цунамі (моретрясіння), сильний шторм, складна льодова обстановка;

5. Геліофізичні: біомагнітні бурі, підвищена сонячна активність, порушення умов розповсюдження радіохвиль (магнітні бурі);

6. Біологічні (біологосоціальні): епідемії - масові захворювання людей, епізоотії - масові захворювання тварин, епіфітотії - масові захворювання рослин;

7. Природні пожежі: лісові, торф'яні, степові;

8. Космічні: астероїди, комети, випромінювання, міжпланетна гравітація.

Вивчення умов виникнення екстремальних природних явищ дозволяє виявити і сформулювати закономірності взаємодії біологічних і фізичних підсистем навколишнього середовища, забезпечивши тим самим можливість хоча б статистичного прогнозу небезпечних природних явищ.

Найбільш визнаною класифікацією природних катастроф за типами i видами є така класифікація:

1) Катастрофи тренду, до яких відносяться несприятливі зміни клімату, вікові зміни рівня моря і абразія берегів.

2) Катастрофи екстремуму, що включають посухи, заморозки і повені.

3) Катастрофи зриву, що охоплюють повені, тропічні шторми, землетруси, виверження вулканів, шторми, торнадо, зсуви, цунамі, пожежі, снігові лавини й селі. 
Кожна 3 цих категорій обумовлена сукупністю процесів у навколишньому середовищі, ранжування яких за потужністю і виділення 3 них найбільш небезпечних вимагає створення таких систем моніторингу навколишнього середовища, які 6 з високою імовірністю виділяли чинники розвитку конкретної природної катастрофи. Хоча механізми і динаміка зародження природних катастроф відрізняються, проте існують загальні принципи виявлення ознак різкої зміни характеристик навколишнього середовища.

Дані, наведені в табл. 1, характеризують різноманітність небезпечних природних процесів і дають стислий опис механізмів їх зародження і розвитку.

Таблиця 1 - Класифікація небезпечних природних процесів [2]

\begin{tabular}{|c|c|}
\hline $\begin{array}{c}\text { Тип небезпечного } \\
\text { природного процесу }\end{array}$ & Стисла характеристика \\
\hline 1 & 2 \\
\hline $\begin{array}{l}\text { Космогенні } \\
\text { небезпечні процеси }\end{array}$ & $\begin{array}{l}\text { Найбільш яскравим проявом космогенних процесів } є \\
\text { магнітні бурі. Це сильні зміни магнітного поля Землі, які } \\
\text { викликаються дією посилених потоків сонячної плазми } \\
\text { (сонячного вітру) на магнітосферу Землі. Відбувається } \\
\text { порушення біологічної ритміки, що призводить до } \\
\text { збільшення серцево-судинних захворювань. }\end{array}$ \\
\hline $\begin{array}{l}\text { Комети, астероїди, } \\
\text { метеорити та } \\
\text { метеорний пил }\end{array}$ & $\begin{array}{l}\text { Залежно від розмірів космічного тіла, яке увійшло в } \\
\text { атмосферу Землі, можуть виникати небезпеки для населення } \\
\text { при їх падінні на сушу або може відбуватися забруднення } \\
\text { атмосфери метеорним пилом } 3 \text { наслідками для клімату } \\
\text { планети. Реальну глобальну небезпеку становлять астероїди } \\
\text { розміром понад } 1 \text { км. }\end{array}$ \\
\hline Озонові діри & $\begin{array}{lrclr}\text { Невеликі } & \text { зміни } & \text { кількості озону } & \text { в атмосфері можуть } \\
\text { призвести } & \text { до } & \text { серйозних } & \text { змін } & \text { інтенсивності } \\
\text { ультрафіолетового } & \text { опромінення } & \text { земної } & \text { поверхні } \\
\text { непередбачуваними наслідками для населення. }\end{array}$ \\
\hline $\begin{array}{l}\text { Торнадо, смерчі, } \\
\text { урагани }\end{array}$ & 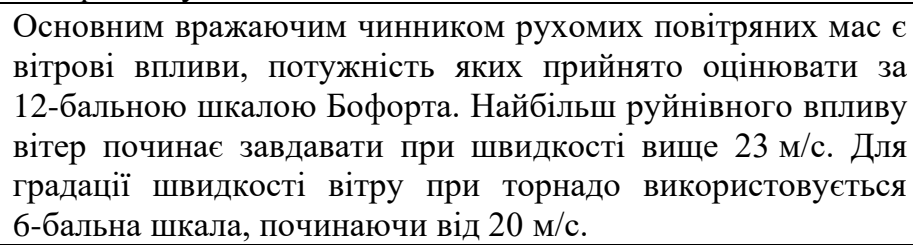 \\
\hline Дощі, грози & $\begin{array}{l}\text { Ці гідрометеорологічні явища зазвичай супроводжують } \\
\text { урагани і бурі, посилюючи руйнування. Випадання рідких } \\
\text { атмосферних опадів протягом декількох діб створюють } \\
\text { повені, ерозію, селі і зсуви в горах. Грози призводять до } \\
\text { загибелі людей та пошкоджень електромереж, а також } \\
\text { викликають лісові пожежі. }\end{array}$ \\
\hline $\begin{array}{l}\text { Небезпечні } \\
\text { природні явища в } \\
\text { атмосфері зимового } \\
\text { періоду }\end{array}$ & $\begin{array}{l}\text { Сильний снігопад, хуртовина, ожеледь, мороз, льодові } \\
\text { явища: ожеледь, ожеледиця, зледеніння. Ці явища можуть } \\
\text { порушувати функціонування транспортних магістралей і } \\
\text { систем життєзабезпечення, руйнувати споруди і знижувати } \\
\text { ефективність економічних структур. }\end{array}$ \\
\hline $\begin{array}{l}\text { Небезпечні } \\
\text { природні явища в } \\
\text { атмосфері літнього } \\
\text { періоду }\end{array}$ & $\begin{array}{l}\text { Спека, посухи, суховії. Сильна тривала спека призводить до } \\
\text { зниження врожаю в сільському господарстві, підвищує ризик } \\
\text { виникнення багатьох захворювань і лісових пожеж, чинить } \\
\text { виснажливий вплив на запаси води і знижує родючість грунтів. }\end{array}$ \\
\hline
\end{tabular}


Продовження табл. 1

\begin{tabular}{|c|c|}
\hline 1 & 2 \\
\hline $\begin{array}{l}\text { Метеогенно- } \\
\text { біогенні небезпечні } \\
\text { природні явища }\end{array}$ & $\begin{array}{l}\text { Природні пожежі (степові, лісові, підземні) призводять до } \\
\text { знищення лісових масивів, загибелі тварин і рослин, } \\
\text { забруднення атмосфери, порушення теплового балансу, } \\
\text { ерозії грунту. У ряді випадків природні пожежі є причиною } \\
\text { загибелі людей. }\end{array}$ \\
\hline $\begin{array}{l}\text { Гідрологічні та } \\
\text { гідрогеологічні } \\
\text { небезпечні природні } \\
\text { процеси }\end{array}$ & $\begin{array}{l}\text { Повені (водопілля та паводки), зажори, затори, полої, } \\
\text { підземні льоди, термокарст, ранні прибережні льод, } \\
\text { суцільний крижаний покрив в портах, обледеніння суден та } \\
\text { портових споруд, морські та гірські льоди, тайфуни, сильні } \\
\text { хвилювання на морі, вітрові нагони, хвильова абразія берегів } \\
\text { морів і океанів, коливання рівня грунтових вод, коливання } \\
\text { рівня вод закритих водойм, карст, суфозія. }\end{array}$ \\
\hline $\begin{array}{l}\text { Геологічні } \\
\text { небезпечні природні } \\
\text { процеси }\end{array}$ & $\begin{array}{l}\text { Тектонічні (тривалі коливання рівня Світового океану, } \\
\text { виверження вулканів, землетруси, гірські удари, } \\
\text { розрідження грунту); геофізичні (геопатогенні, радіогенні) і } \\
\text { геохімічні (ореоли родовищ); схилові процеси (обвали, } \\
\text { каменепади, осипи, куруми, зсуви, селі, лавини, пульсуючі } \\
\text { льодовики, площинні схилові змиви, кріп, солифлюкція, } \\
\text { дефлюкція, просадка лесових порід, ерозія схилів, ерозія } \\
\text { річкових берегів); завальні і льодовикові повені; вітрова } \\
\text { ерозія грунтів (пилові бурі). }\end{array}$ \\
\hline
\end{tabular}

Стихійні лиха - це небезпечні природні явища геофізичного, геологічного, атмосферного або біосферного походження, які характеризуються раптовим порушенням життедіяльності населення, руйнуваннями, знищенням матеріальних цінностей, травмами і жертвами серед людей.

Стихійне лихо - руйнівне природне явище або процес значного масштабу, в результаті якого може виникнути або виникла загроза життю і здоров'ю людей, статися руйнування чи знищення матеріальних цінностей $\mathrm{i}$ компонентів навколишнього природного середовища. В результаті стихійних лих страждає економіка країни, так як при цьому руйнуються виробничі підприємства, знищуються матеріальні цінності, гинуть люди. Крім того, стихійні лиха створюють несприятливі умови для життя населення, що може бути причиною спалахів масових інфекційних захворювань. Кількість постраждалих від стихійних лих людей може бути досить значною, а характер уражень дуже різноманітним. Найбільш руйнівними 3 існуючих видів небезпечних природних явищ $є$ повені, підтоплення, ерозія, землетруси, зсуви, селі, карсти, суффозії, гірські удари, снігові лавини, урагани, штормові вітри, смерчі і ін. 3 усіх природних процесів і явищ найбільший економічний збиток наносять повені, тропічні шторми, посухи і землетруси, вони ж є найбільш небезпечними для життя i здоров'я людей. Аналіз розвитку природних небезпек сьогодні дозволяє зробити висновок про те, що, незважаючи на науково-технічний прогрес, захищеність людей і матеріальної сфери від грізних явищ і процесів природи не підвищується. Щорічний приріст числа загиблих від природних катастроф у світі становить 4,3\%, постраждалих $8,6 \%$, а величини матеріального збитку - $10,4 \%$. В цілому на землі від природних катастроф гине кожна стотисячна людина, а за останні сто років 16 тис. щорічно. 


\section{Аналіз динаміки природних катастроф}

Природні катастрофи в загальноприйнятому їх розумінні завжди були одним 3 елементів глобальної екодинаміки. Стихійні лиха і різні природні катаклізми в минулому відбувалися відповідно до розвитку природних трендів, а починаючи 3 XIX століття на їх динаміку почали впливати антропогенні фактори. В цілому поряд 3 процесами дестабілізації клімату спостерігається зростання числа катастрофічних явищ. Рис. 1-4 дають певне уявлення про динаміку кількості природних катастроф і пов'язаних з ними лих [3-9].

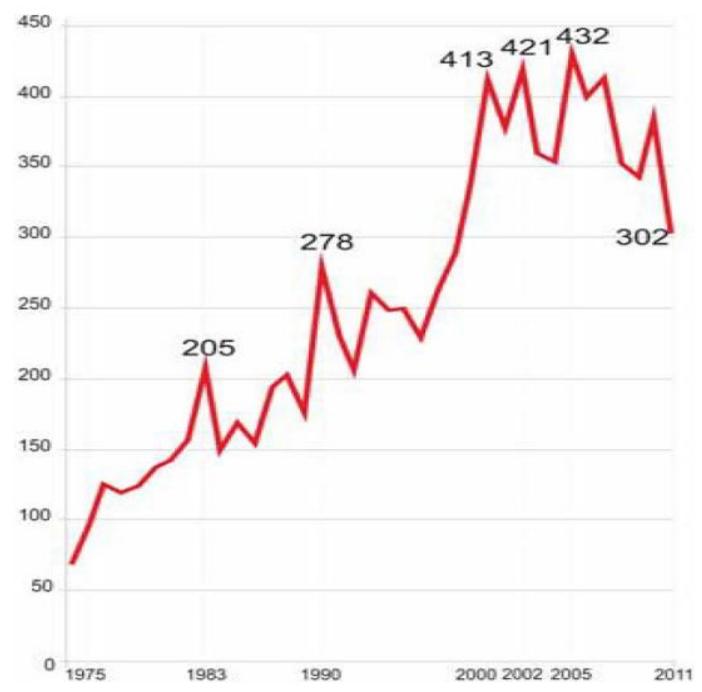

Рис. 1 - Динаміка природних катастроф, що відбулися в світі

На рис. 2 відображена динаміка найбільших природних катастроф.

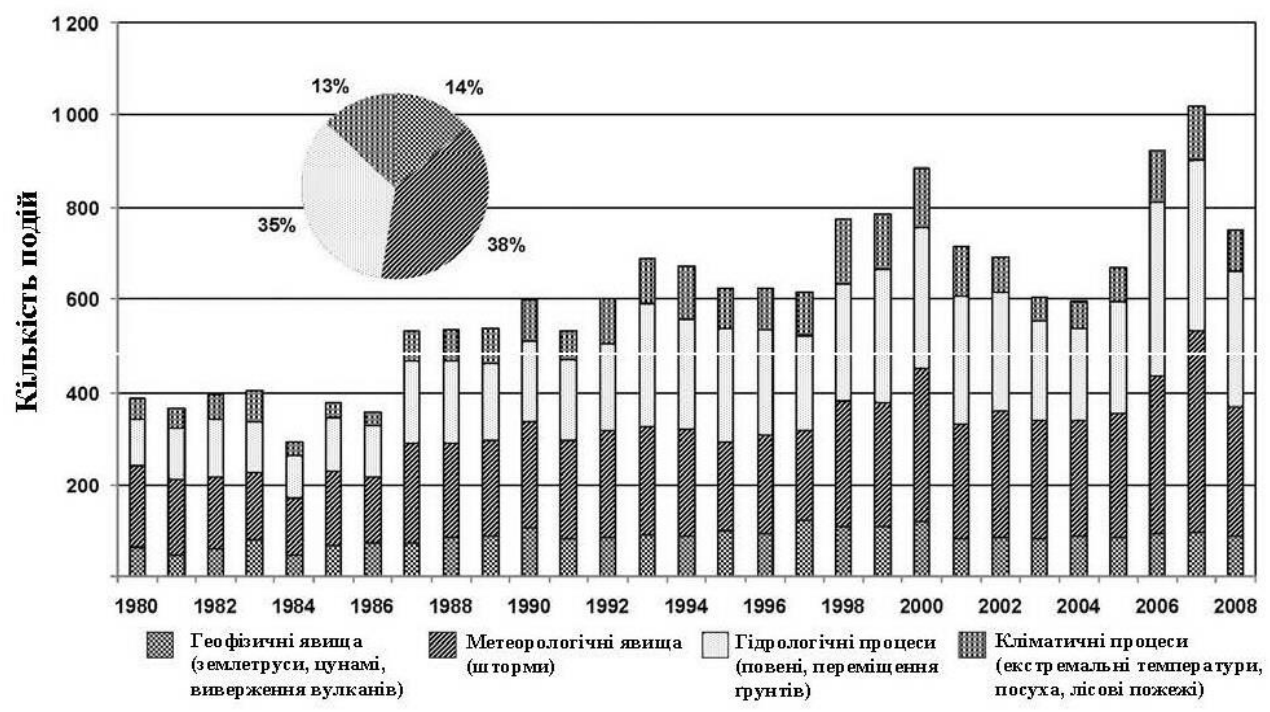

Рис. 2 - Динаміка найбільших природних катастроф 
На рис. 3 наведено загальну кількість стихійних лих, що сталися, за типами.

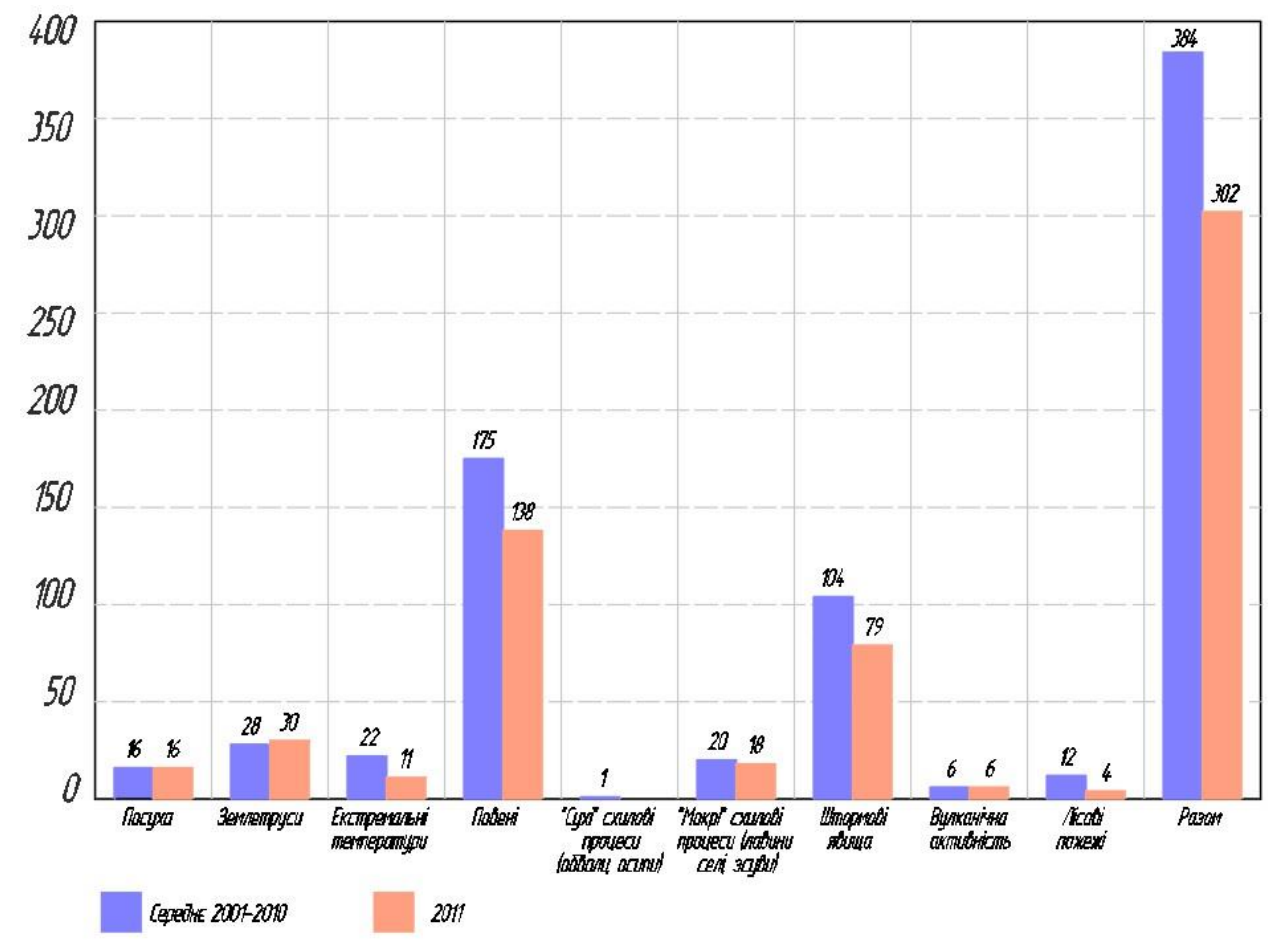

Рис. 3 - Загальна кількість стихійних лих, що сталися, за типами

У табл. 2 наведено розподіл числа жертв за типами природних катастроф за період з 2000 по 2011 pp. [10-14].

Таблиця 2 - Розподіл числа жертв за типами природних катастроф

\begin{tabular}{|l|c|}
\hline \multicolumn{1}{|c|}{ Вид природної катастрофи } & Кількість загиблих \\
\hline Цунамі & 227262 \\
\hline Землетрус & 224016 \\
\hline Тропічні циклони & 158241 \\
\hline Екстремальні температури & 88062 \\
\hline Епідемії & 47281 \\
\hline Повені & 46978 \\
\hline Лавини, зсуви & 6699 \\
\hline Місцеві бурі & 3141 \\
\hline Шторми & 2496 \\
\hline Посуха & 1541 \\
\hline Лісові пожежі & 359 \\
\hline Виверження вулканів & 221 \\
\hline
\end{tabular}

Наведені в табл. 2 дані дозволяють ранжувати кількість жертв і прогнозувати соціальні і економічні втрати від природних катастроф. За кількістю постраждалих перше місце утримує Азія, де налічується 87\% всіх постраждалих від природних катастроф. Тут люди сильніше страждають від 
посухи, хоча на відміну від Африки смертельних випадків в результаті посухи в Азії значно менше. 3 повенями пов'язано близько 40\% всіх постраждалих на азіатському континенті. Відношення числа постраждалих до населення в Азії в 2 рази більше, ніж в Африці, в 6 разів більше, ніж в Америці, в 10 разів більше, ніж в Океанії, і в 40 разів більше, ніж в Свропі.

Швидкими темпами зростають економічні втрати від цунамі, землетрусів $\mathrm{i}$ тропічних циклонів. На їх частку в 1990-2011 рр. припадає до 85\% прямих економічних втрат в світі. В цілому за три останніх десятиліття економічні втрати від цих лих потроїлися: в 70-х роках вони становили 40 млрд дол., у 80-х 70 млрд дол., а в 90-х - 190 млрд дол. У 2000-2010 рр. збитки перевищили 170 млрд дол. Статистичний аналіз тренду показує: якщо не вжити термінових заходів, сумарна величина економічних втрат від природних катастроф у 2020-ті роки досягне 300 млрд дол. За останні десятиліття намітилось неухильне зростання кількості катастроф і шкоди від них, різноманітність і характер протікання цих явищ постійно змінюється і ускладняється [15-18].

Кількість постраждалих і загиблих в результаті стихійних лих за 2011 р. в порівнянні із середніми значеннями за останнє десятиліття наведено на рис. 4.

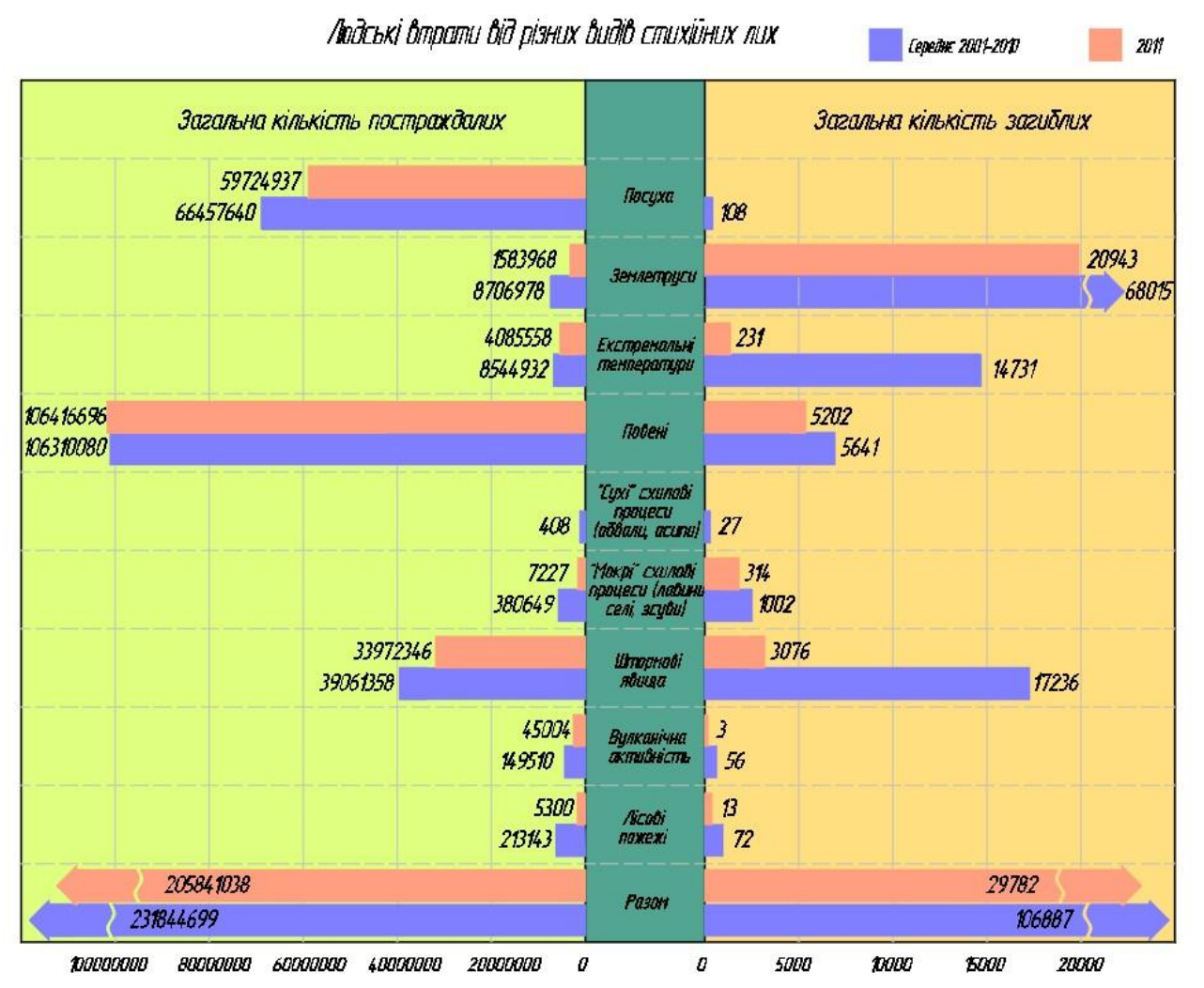

Рис. 4 - Кількість постраждалих і загиблих в результаті стихійних лих за 2011 р. в порівнянні із середніми значеннями за останнє десятиліття

Щорічно на Земній кулі серед безлічі природних катастроф виділяються найбільш значущі, як за людськими жертвами, так і за економічним збитком. На рис. 5 і 6 відображені збитки, завдані природними катастрофами за період 1980-2008 pр., та показана їх структура [19-22]. 


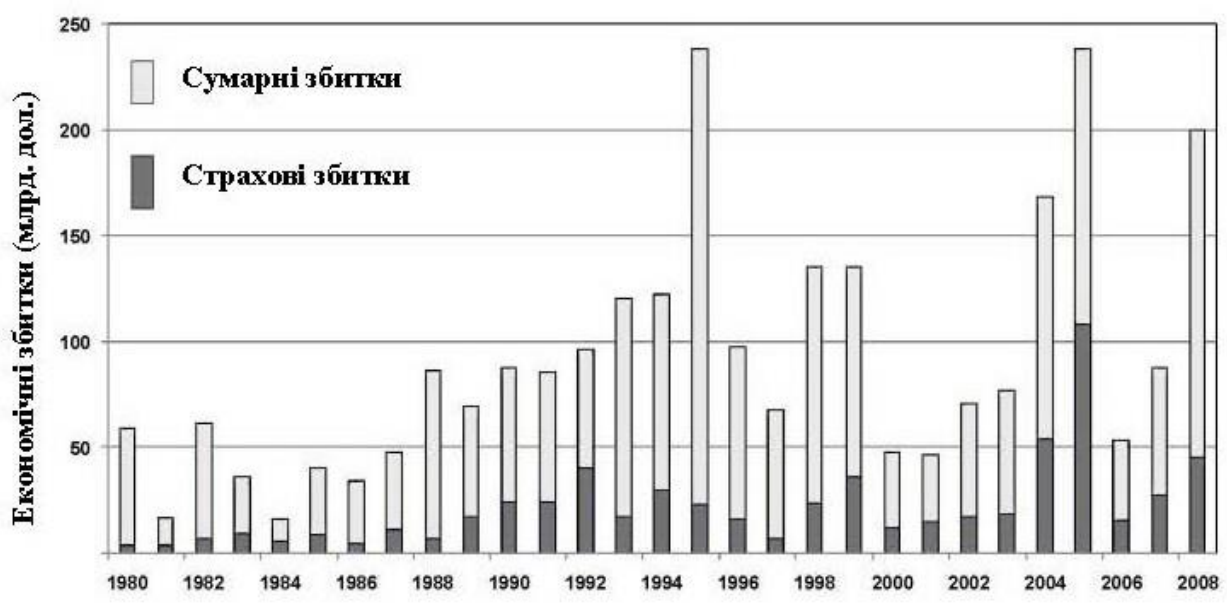

Рис. 5 - Середній збиток (млрд доларів), заподіяний природними катастрофами

Розподіл збитків, заподіяних природними катастрофами, наведений на рис. $6[22,23]$.

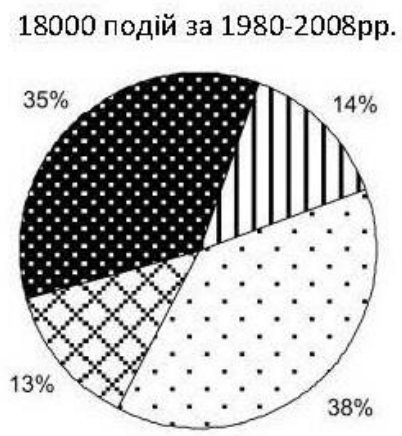

Сүмарний економічний збиток склав 2600 млрд. дол.

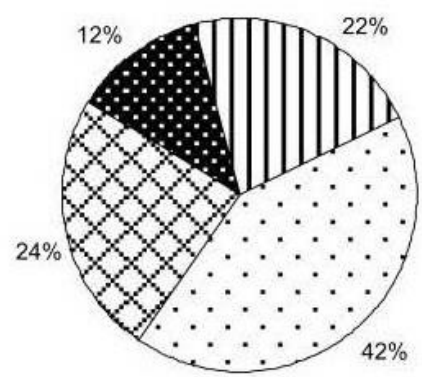

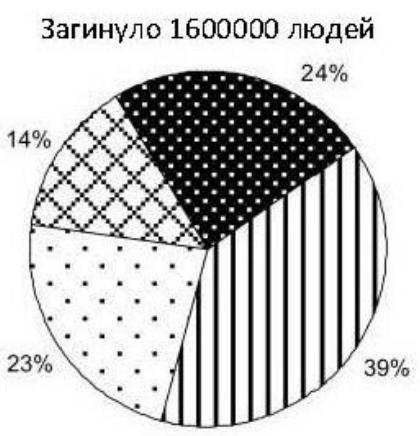

Страхові збитки склали 630 млрд. дол.

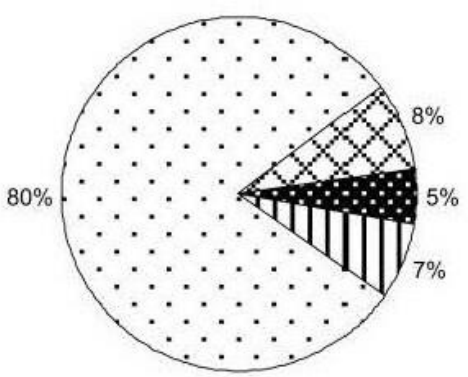

ПГГеофізичні явища (землетрүси, цұнамі, виверження вұлканів)

$\square$ Метеорологічні явища (шторми)

О Гідрологічні явища (повені, переміщення грүнтів)

. Кліматичні процеси (екстремальні температүри, посүхи, лісові пожежі)

Рис. 6 - Розподіл збитків, заподіяних природними катастрофами 
3 даних, наведених на рис. 5 і 6, видно, що витрати страхових компаній, пов'язані 3 природними катастрофами значно збільшилися. Частка застрахованих збитків становить не більше $40 \%$ від загального економічного збитку. У ряді країн, що розвиваються, економічні збитки від природних катастроф перевищують величину валового національного продукту, в результаті чого економіка цих країн переходить в критичний стан.

Якщо в 2015 році збитки світової економіки внаслідок природних катастроф були оцінені в 220 млрд доларів США, що в три рази більше ніж у 2010 році, то на початку 2018 року вони вже перевищили суму збитків 2015 року майже в 2 рази [24].

Це обумовлено комплексом різних природних загроз та викликів. Існує тісний взаємозв'язок між кількістю загиблих і потерпілих від катастроф і середнім рівнем життя [25-27]. При зменшенні вартості валового національного продукту на одного жителя 310 тис. дол. до 200-300 дол. на рік, число катастроф, яким піддавався кожен житель в 1990-2010 рр., зростає від 0.006 до 6 - в 1000 разів (рис. 7) [28].

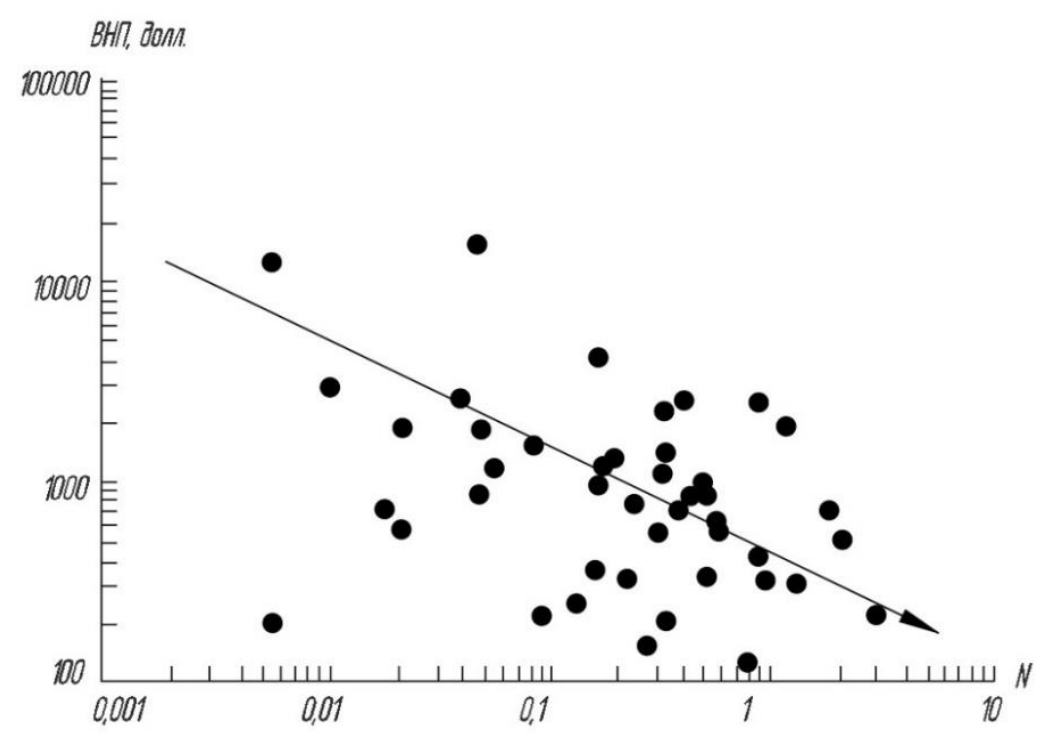

Рис. 7 - Залежність між величиною валового національного продукту, розрахованого на одного жителя країни, і числом природних катастроф $(\mathrm{N})$, яким піддавався кожен ії житель

\section{Висновки}

3 аналізу наведених у даній роботі міркувань щодо динаміки природних катастроф, соціальних і економічних збитків від них можна зробити висновки, головні з яких такі.

1. За останні десятиліття намітилось неухильне зростання кількості природних катастроф і шкоди від них, різноманітність і характер протікання цих явищ постійно змінюється і ускладняється.

2. Виникнення природних катастроф - це системне явище, тобто вони відбуваються під впливом багатьох чинників. 
3. Природні катастрофи можуть мати масштаби від локального до глобального, і їх різновиди безперервно збільшуються.

4. Кількість природних катастроф, людських жертв і економічних збитків у світі з кожним роком різко зростає.

5. Виникла необхідність розробки нової стратегії, єдиної теорії i практичних методів забезпечення безпеки, які передбачають комплексний підхід до катастрофічних стихійних явищ.

6. Для практичної реалізації нової стратегії необхідно націлити науковотехнологічний потенціал сучасного світу на створення методів і засобів прогнозування та попередження i, перш за все, на оцінку ризику, розробку превентивних заходів, попередження та забезпечення готовності до природних катастроф і стихійних лих.

\section{СПИСОК ЛІТРРАТУРИ}

1. Данилов-Данильян В.И., Лосев К.С. (2000) Экологический вызов и устойчивое развитие. М.: Прогресс-традиция. $416 \mathrm{c.}$

2. Мазур И.И., Иванов О.П. (2004) Опасные природные процессы. - М.: Экономика. $702 \mathrm{c}$.

3. Осипов В.И. (2001) Природные катастрофы на рубеже XXI века // Наука и общество. № 4. - С. 291-302.

4. Abrahamson D.E. (1989) Challenge of Global Warming. Island Press, Washington, $376 \mathrm{pp}$.

5. Beven II J.L., Avila L.A., Blake E.S., Brown D.P., Franklin J.L., Knabb R.D., Pasch R.J., Rhome F.R. and Stewart S.R. (2008) Annual Summary: Atlantic Hurricane Season of 2005 // Monthly Weather Review (American Meteorological Society). V. 136(3). P. 1131-1141.

6. Blowers A. and Hinchliffe S. (2003) Environmental Responses. Wiley, London, 312 pp.

7. Bohle H. (2001) Vulnerability and criticality: perspectives from social geography // IHDP Update, 2, pp. 231-239.

8. Bras R.L. (1990) Hydrology. New York: Addison-Wesley. 643 pp.

9. Delgado J.P. (1998) Encyclopedia of underwater and maritime archaeology. New Haven, London, $135 \mathrm{pp}$.

10. Enz R. (2006). Natural catastrophes and man-made disasters 2005 // Sigma. No. 2. P. 140.

11. Enz R., Karl K., Mehlhorn J., and Schwarz S. (2008) Natural catastrophes and man-made disasters: High losses in Europe // Sigma. No. 1. P. 1-48.

12. Field C.B. and Raupach M.R. (eds) (2004) Global Carbon Cycle: Integrating Humans, Climate, and the Natural World. Washington: Island Press. $584 \mathrm{p}$.

13. Field J.G., Hempel G., and Summerhayer C.P. (eds) (2002) Oceans 2020: Science Trends and the Challenge of Sustainability. Washington: Island Press. 296 p.

14. Flood J. (1995) Indicators for the implementation and monitoring of Agenda // Habitat, vol. 1 , No. 5 , p. 13.

15. Gardner J.S. (2002) Natural hazards risk in the Kullu District, Himachal Pradesh, India // The Geographical Review, vol. 92, pp. 172-177.

16. Gutberlet J. (2003) Cities, consumption and the generation of waste // Aviso, No. 11, pp. 12-19.

17. Hardy J.T. (2003) Climate Change. Washington: Wiley. 260 p.

18. Lanchester F.W. (1917) Aircraft in warfare, the dawn of the Fourth Arm. London: Constable and company limited. P. 30-41.

19. McNulty S.G. (2002) Hurricane impacts on US forest carbon sequestration // Environmental Pollution, vol. 116, P. 17-24. 
20. Milne A. (2004) Doomsday: The Science of Catastrophic Events. Westport: Praeger Publisher. $194 \mathrm{p}$.

21. Morris J. (1997) Introduction: Climate change - prevention or adaptation? // IEA Stud. Educ., No. 10, pp. 13-37.

22. Notron R. (2002). Early Eighteenth-Century Newspaper Reports: A Sourcebook "Natural Catastrophes", http: //www.infopt.demon.co.uk /grub/ catastro.htm

23. Posner R.A. (2004) Catastrophe: Risk and Response. Oxford Univ. Press, Oxford, 332 p. 24. Richter C.F. (1969) Earthquakes // Natural History. V. 78. P. 37-45.

25. Schneider D. (1995) Global warming is still a hot topic // Scientific American. V. 272(2). P. 13-14.

26. Vogel C. and O'Brien K. (2004) Vulnerability and global environmental change: rhetoric and reality // Aviso (An International Bulletin on Global Environmental Change and Human Security), no. 13, pp. 1-8.

27. Walker G. (2003) Snowball Earth: The Story of the Great Global Catastrophe that Spawned Life as We Know It. Crown Publishers, New York, 269 pp.

28. WI (2009) State of the World 2009: Into a warming World. Washington: World watch Institute. 262 p.

29.Zanetti A., Schwarz S., and Lindemuth S. (2007) Natural catastrophes and man-made disasters in2006: Low insured losses // Sigma. No. 2. P. 1-40.

30.Zimmerli P. (2003) Natural catastrophes and reinsurance. Zurich (Switzerland): Swiss Reinsurance Company. 48 p.

Стаття надійшла до редакиії 03.10.2019 і прийнята до друку після рецензування 28.10.2019

\section{REFERENCES (TRANSLATED AND TRANSLITERATED)}

1. Danilov-Danil'yan, V. I., \& Losev, K. S. (2000). Ekologicheskiy vyzov i ustoychivoye razvitiye. Moscow: Progress-traditsiya. (in Russian).

2. Mazur, I. I., \& Ivanov, O. P. (2004). Opasnye prirodnyye protsessy. Moscow: Ekonomika. (in Russian).

3. Osipov, V. I. (2001). Prirodnyye katastrofy na rubezhe XXI veka. Nauka i obshchestvo, (4), 291-302. (in Russian).

4. Abrahamson, D. E. (1989). Challenge of Global Warming. Washington: Island Press.

5. Beven II, J. L., Avila, L. A., Blake, E. S., Brown, D. P., Franklin, J. L., Knabb, R. D., Pasch, R. J., Rhome, F. R. \& Stewart, S. R. (2008). Annual Summary: Atlantic Hurricane Season of 2005. Monthly Weather Review (American Meteorological Society), 136(3), 11311141.

6. Blowers, A., \& Hinchliffe, S. (2003). Environmental Responses. Wiley, London.

7. Bohle, H. (2001). Vulnerability and criticality: perspectives from social geography. IHDP Update, (2), 231-239.

8. Bras, R. L. (1990). Hydrology. New York: Addison-Wesley.

9. Delgado, J. P. (1998). Encyclopedia of underwater and maritime archaeology. New Haven, London.

10. Enz, R. (2006). Natural catastrophes and man-made disasters 2005. Sigma, (2), 1-40.

11. Enz, R., Karl, K., Mehlhorn, J., \& Schwarz, S. (2008). Natural catastrophes and manmade disasters: High losses in Europe. Sigma, (1), 1-48.

12. Field, C. B., \& Raupach, M. R. (Eds.). (2004). Global Carbon Cycle: Integrating Humans, Climate, and the Natural World. Washington: Island Press.

13. Field, J. G., Hempel, G., \& Summerhayer, C. P. (Eds.). (2002). Oceans 2020: Science Trends and the Challenge of Sustainability. Washington: Island Press.

14. Flood, J. (1995). Indicators for the implementation and monitoring of Agenda. Habitat, 1(5), 13 . 
15. Gardner, J. S. (2002). Natural hazards risk in the Kullu District, Himachal Pradesh, India. The Geographical Review, 92, 172-177.

16. Gutberlet, J. (2003). Cities, consumption and the generation of waste. Aviso, (11), 12-19. 17. Hardy, J. T. (2003). Climate Change. Washington: Wiley.

18. Lanchester, F. W. (1917). Aircraft in warfare, the dawn of the Fourth Arm. London: Constable and company limited.

19. McNulty, S. G. (2002). Hurricane impacts on US forest carbon sequestration. Environmental Pollution, 116, S17-S24.

20. Milne, A. (2004). Doomsday: The Science of Catastrophic Events. Westport: Praeger Publisher.

21. Morris, J. (1997). Introduction: Climate change - prevention or adaptation. IEA Stud. Educ., (10) 13-37.

22. Notron, R. (2002). Early Eighteenth-Century Newspaper Reports: A Sourcebook "Natural Catastrophes", Retrieved from http://www.infopt.demon.co.uk/grub/ catastro.htm 23. Posner, R. A. (2004). Catastrophe: Risk and Response. Oxford: Oxford Univ. Press.

24. Richter, C. F. (1969). Earthquakes. Natural History, (78), 37-45.

25. Schneider, D. (1995). Global warming is still a hot topic. Scientific American, 272(2), 13-14.

26. Vogel, C., \& O'Brien K. (2004). Vulnerability and global environmental change: rhetoric and reality. Aviso (An International Bulletin on Global Environmental Change and Human Security), (13), 1-8.

27. Walker, G. (2003). Snowball Earth: The Story of the Great Global Catastrophe that Spawned Life as We Know It. New York: Crown Publishers.

28. WI (2009). State of the World 2009: Into a warming World. Washington: World watch Institute.

29. Zanetti, A., Schwarz, S., \& Lindemuth, S. (2007). Natural catastrophes and man-made disasters in 2006: Low insured losses. Sigma, (2), 1-40.

30. Zimmerli, P. (2003). Natural catastrophes and reinsurance. Zurich (Switzerland): Swiss Reinsurance Company.

The article was received 03.10.2019 and was accepted after revision 28.10.2019

\section{Азаров Сергій Іванович}

доктор технічних наук, старший науковий співробітник, провідний науковий співробітник Інституту ядерних досліджень НАН України

Адреса робоча: 03680 Україна, м. Київ, пр-т Науки, 47

e-mail: azarov@kinr.kiev.ua

ORCID ID 0000-0002-9951-8867

\section{Задунай Олексій Сергійович}

кандидат технічних наук, начальник центру Державного науково-дослідного інституту технологій кібербезпеки та захисту інформації

Адреса робоча: 03142 Україна, м. Київ, вул. М. Залізняка, 6

e-mail: a.zadunaj@gmail.com

ORCID ID 0000-0001-8589-1604 